\title{
A tale of three lamproites, their diamonds and settings - Bunder, Majhgawan and Argyle
}

\author{
Chris B. Smith ${ }^{1}$, Galina Bulanova ${ }^{1}$, Venkatasubramanian Meenakshisundaram ${ }^{2}$ and \\ Lynton Jaques ${ }^{3}$ \\ ${ }^{1}$ University of Bristol, United Kingdom, chris_b_smith@btopenworld.com,galina_bulanova@hotmail.com \\ ${ }^{2}$ Rio Tinto Exploration India Private Limited, Bangalore, India, venkat@ riotinto.com \\ ${ }^{3}$ Australian National University, Canberra, Australia, lynton.jaques@anu.edu.au
}

Bunder pipes (Madhya Pradesh, India), Majhgawan (Madhya Pradesh, India) and Argyle (Western Australia) (Fig. 1) are Mesoproterozoic diamondiferous diatremes with affinities to lamproite, as characterised by their ultrapotassic nature, high content of $\mathrm{Sr}, \mathrm{Zr}, \mathrm{Nb}, \mathrm{La}$ and $\mathrm{Ba}$ and LREE, former glassy matrix, and the presence of characteristic minerals such as priderite, potassic richterite, Ti-rich tetraferriphlogopite and leucite (Argyle; Jaques et al., 1986), tetraferriphlogite (Bunder and Majhgawan; Masun et al., 2009; Farreduddin and Mitchell, 2012). Lamproites are regarded as lithospheric mantle-derived melts (Mitchell and Bergman, 1991). However, $\mathrm{Sr}$ and $\mathrm{Nd}$ isotopic compositions suggest a greater input from the asthenospheric mantle in the case of the Indian pipes (Das et al., in press.), and the presence of picroilmenite megacrysts at Bunder (Masun et al., 2009) and Mahjgawan (Mukherjee et al., 1997) suggests derivation from the low velocity zone at the base of the lithospheric mantle, a feature associated with Group I kimberlites rather than lamproite (Mitchell and Bergman, 1991). Such conflicting features led Chalapathi Rao (2015) to suggest that Majhgawan (and hence also Bunder) are transitional between kimberlite and lamproite.

All three occurrences lie within or adjacent to Proterozoic orogenic belts representing former tectonic collision zones between cratons. Bunder and Majhgawan lie on the edge of the Archean Bundelkhand Craton next to the Central Indian Tectonic Zone ("CITZ") and tap diamonds sourced from the underlying peridotitic mantle (Fig. 1a). These two Indian lamproites lie on the ENE trending Asmara seismic lineament (interpreted as a fault in the crystalline basement (Helmstaedt, in press; Prasad and Rao, 2006). The CITZ is seismically active and marks the major Precambrian (1.6-1.5 and 1.1-1.0 Ga) zone of collision of the Bundelkhand and Bastar Cratons during formation of the Rodinia supercontinent. Argyle lies within the strongly faulted Paleoproterozoic Halls Creek Orogen ("HCO") adjacent to the Kimberley Craton (Fig. 1b). The HCO marks the Paleoproterozoic collision of the Archean Kimberley and North Australian Cratons. The HCO remained tectonically active during the Proterozoic and has been further deformed by later NE-SW faulting (Betts et al., 2015; Helmstaedt, in press; Tyler et al., 2012). Argyle diamonds are predominately eclogitic, possibly derived from subducted North Australian Craton crust (Fig. 1b). It is suggested these highly fractured, tectonically active, collision zones facilitated and enhanced interaction of asthenosphere-derived, alkali-rich fluids with overlying lithospheric mantle, giving rise after partial lithospheric mantle melting to the chemically enriched nature of resultant magmas with lamproite affinities.
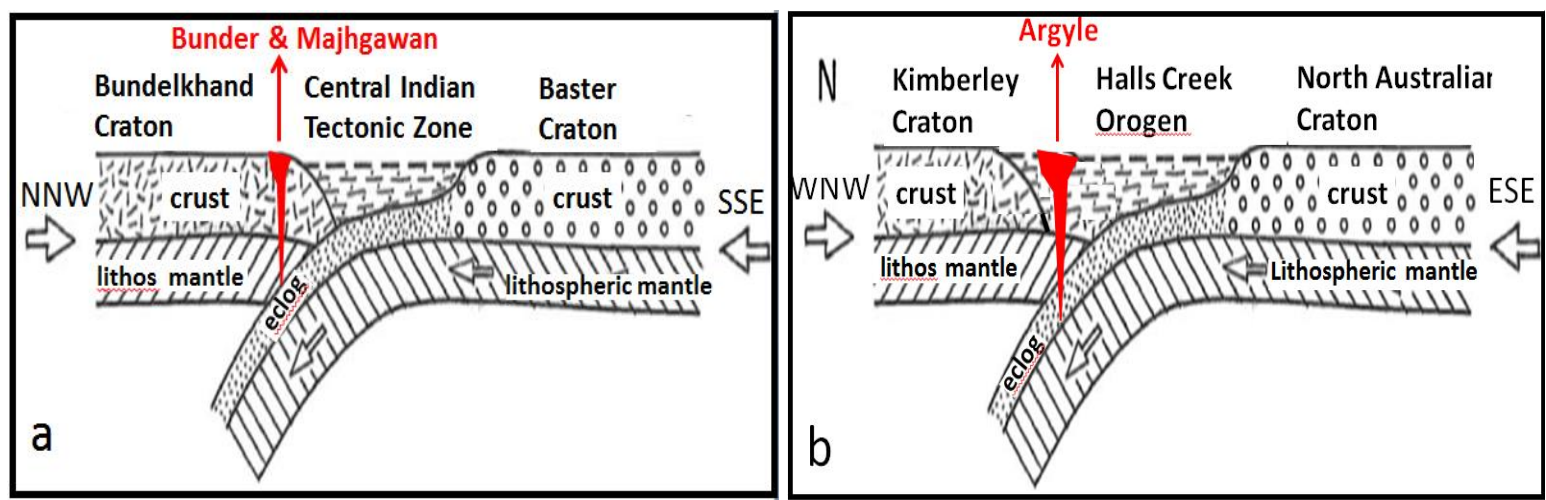

Fig. 1: a) Bunder X-section (based on Mandal et al., 2013), b) Argyle X-section (based on Tyler et al., 2012); images are interpreted from seismic tomography, with suggested pipe locations superimposed upon them. 
The three occurrences have significant diamond content. The Atri pipe at Bunder has an inferred resource of 37 million tonne, containing 27.4 million cts. Majhgawan and surrounding alluvials at Panna are one of the world's oldest mined diamond deposits, with production dating back to the 13th century. Argyle has been the world's largest diamond producing pipe, realising some 825 million cts since 1983. The diamonds from these three pipes, considered to be formed from fluids in cracks within lithospheric mantle peridotite and eclogite, show signs of stress with common development of plastic deformation and associated brown colour (Fig. 2 due to resultant vacancy cluster defects.
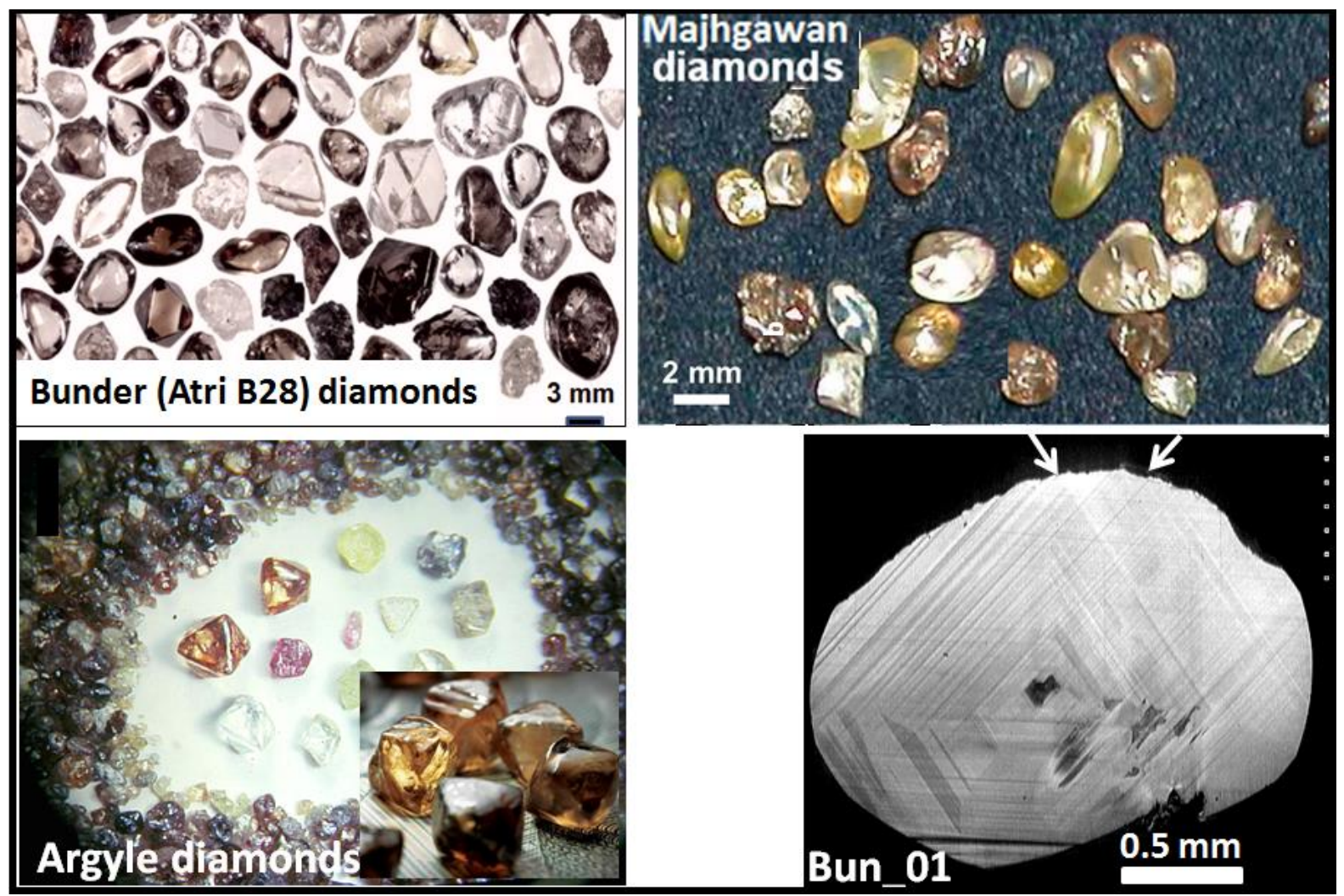

Fig. 2: Images of diamonds from Bunder, Majhgawan and Argyle. Note prominent brown colours. Bunder diamond Bun_01 shows prominent plastic deformation in two directions indicated by white arrows.

Such brown colour is found in diamonds of both peridotitic and eclogitic mantle hosts (Bulanova et al., in press). Bunder diamonds carry predominantly peridotitic inclusions of olivine $\left(\sim \mathrm{FO}_{92}\right)$ and high $\mathrm{Cr}$ magnesiochromite suggestive of a harzburgitic domain, with a minor eclogitic component indicated by a kyanite inclusion (Smith et al., in press.). Majhgawan has inclusions of olivine, diopside, garnet and spinel (Fareeduddin and Mitchell, 2012). At Argyle, diamonds with eclogitic inclusions predominate $(>90 \%)$ over peridotitic stones. The eclogitic diamonds have predominantly light $\mathrm{C}$-isotopic compositions, contain mineral inclusions with high $\delta^{18} \mathrm{O}$ values, and are inferred to have formed from subducted crustal carbon (Stachel et al., in press). Diamonds, also mainly brown in colour, have been recovered from peridotite xenoliths at Argyle (Jaques et al., 1990).

FTIR data indicate that Argyle diamonds have highly aggregated $\mathrm{N}$. Temperatures calculated from $\mathrm{N}$ aggregation and mineral inclusions give main ranges of $1120-1250^{\circ} \mathrm{C}$ for Argyle peridotitic diamonds and 1240-1300 for eclogitic stones (Bulanova et al., in press.; Jaques et al. in press.; Stachel et al., in press.) This contrasts with the more moderately aggregated $\mathrm{N}$ in Bunder diamonds with indicated temperatures of $1140-1200^{\circ} \mathrm{C}$ ( Smith et al., in press).

\section{Conclusions}

We therefore suggest a link between stress conditions in tectonic collision zones and adjacent craton margins and development both of diamonds, often brown and plastically deformed, and of host rocks of lamproite affinity. Such faulted and fractured terrains facilitate movement of fluids and magmas 
and thus provide a craton margin diamond exploration target, alternative to traditional search for classical kimberlites in more central, structurally less disturbed, interior craton settings.

\section{References}

Betts PG, Armit RJ, Stewart J, Aitken RAA, Ailleres L, Donchak P, Hutton L, Withnall L, and Giles D, (2015) Australia and Nuna. In: Li ZX, Evans DAD, Murphy JB, Eds., Supercontinent Cycles Through Earth History, Geological Society of London Special Publications, v. 424., pp. 47-81.

Bulanova GP, Speich L, Smith CB, Gaillou L, Kohn SC, Wibberley E, Chapman JG, Howell D, Davy AT (in press) The unique nature of Argyle fancy diamonds: internal structure, paragenesis and reasons for color. In: Geoscience and Exploration of Rio Tinto's diamond deposits. Society of Economic Geologists, Inc., Special Publication.

Chalapathi Rao NV (2005) A petrological and geochemical reappraisal of the Mesoproterozoic diamondiferous Majhgawan pipe of central India: evidence for transitional kimberlite - orangeite (group II kimberlite) - lamproite rock type. Mineralogy and Petrology v. 84, pp. 69-106.

Das H, Kobussen AF, Webb K, Phillips D, Maas R, Soltys A, Howell D (in press) The Bunder diamond project, India: geology, petrography, geochemistry and age of the diamondiferous Atri pipes. In: Geoscience and Exploration of Rio Tinto's diamond deposits. Society of Economic Geologists, Inc., Special Publication.

Fareeduddin, Mitchell RM (2012) Diamonds and their source rocks in India. Geological Society of India, Bangalore, $434 \mathrm{p}$.

Jaques AL, Lewis JD, Smith CB (1986) The kimberlites and lamproites of Western Australia. Geol. Surv. Western Australia, Bull. 132, 268 p.

Jaques AL, O'Neill HStC, Smith CB, Moon J, Chappell BW (1990) Diamondiferous peridotite xenoliths from the Argyle (AK1) lamproite pipe, Western Australia. Contrib Mineral Petrol 104:255-276

Jaques AL, Luguet A, Smith CB, Pearson DG, Yaxley GM, and Kobussen A, (in press) Nature of the mantle beneath the Argyle AK1 lamproite 1 pipe: constraints from mantle xenoliths, diamonds and lamproite geochemistry. In: Geoscience and Exploration of Rio Tinto's diamond deposits. Society of Economic Geologists, Inc., Special Publication.

Helmstaedt H., in press. Tectonic and structural controls on diamondiferous kimberlite and lamproite and their bearing on area selection for diamond exploration. In: Geoscience and Exploration of Rio Tinto's diamond deposits. Society of Economic Geologists, Inc., Special Publication.

Mandal B, Sen MK, Rao VJ (2013) New seismic images of the Central Indian Suture Zone and their tectonic implications. Tectonics, v. 32, pp. 908-921

Masun K, Sthapak AV, Singh A, Vaidya A, Krishna C, (2009) Exploration history and geology of the diamondiferous ultramafic Saptarshi intrusions, Madhya Pradesh, India. $9^{\text {th }}$ IKC Proceedings, Lithos 112S: 142-154

Mitchell RH, Bergman SC (1991) Petrology of Lamproites. Plenum Press, New York, 447 p.

Mukherjee A, Rao KS, Bandyopadhyay D, Roy G (1997) Chemistry of garnet \& ilmenite from Majhgawan diamondiferous pipe, Panna District, vis-a-vis diamond potential and preservation. Journ. Geol. Soc. India, v.50, pp.441-448

Prasad BR, and Vijaya Rao V (2006) Deep seismic reflection study over the Vindhyans of Rajasthan: Implications for geophysical setting of the basin. Journal of Earth System Science, v. 115, pp. 135147.

Smith CB, Bulanova GP, Kobussen A, Burnham A, Chapman J, Davy AT, Sinha KK (in prep.). Diamonds from the Bunder lamproites and implications for the nature of the underlying mantle. In: Geoscience and Exploration of Rio Tinto's diamond deposits. Society of Economic Geologists, Inc., Special Publication.

Stachel T, Harris JW, Hunt L, Muehlenbachs K, Kobussen A, EIMF (in press) Argyle Diamonds How subduction along the Kimberley Craton edge generated the world's biggest Diamond Deposit. In: Geoscience and Exploration of Rio Tinto's diamond deposits. Society of Economic Geologists, Inc., Special Publication.

Tyler IM, Hocking RM, Haines P (2012) Geological evolution of the Kimberley region of Western Australia: Episodes, v. 35, p. 298-306. 